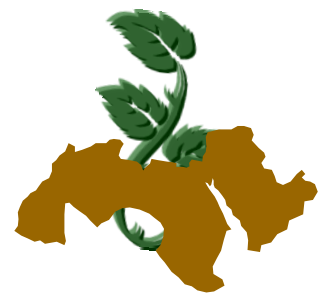

459

Arab Univ.

J. Agric. Sci.,

Ain Shams Univ.,

Cairo, 16(2), 459-468, 2008

\title{
RESPONSE OF SOME SWEET POTATO GENOTYPES TO A SLOW- RE- LEASE NITROGEN FERTILIZER UNDER ASSIUT CONDITIONS
}

\author{
Badawy ${ }^{1}$, A.S. and M.H. Hosseny ${ }^{2}$ \\ 1. Horticulture Research Institute, Agricultural Research Center, Giza, Egypt \\ 2. Horticulture Department, Faculty of Agriculture, Sohag University, Egypt
}

Keywords: Sweet potato, Slow -release fertilizer, Enciabien

\begin{abstract}
This work was carried out during the two summer seasons of 2006 and 2007 at Arab ElAwammer Research Station (A.R.C.); Assiut, Egypt, to study the effect of Enciabien as a slowrelease fertilizer on sweet potato plants grown in newly reclaimed soil. Three genotypes of sweet potato ( two clones Assiut 201, 202 and one cultivar 17/8) and four levels of nitrogen i;e. $20 \mathrm{~N}$ units of ammonium sulphate (control ), $20 \mathrm{~N}$ units , $40 \mathrm{~N}$ units and $60 \mathrm{~N}$ units of Enciabien were used in the present study. The results indicated that applying $60 \mathrm{~N}$ units of Enciabien gave the best result in most of studied characters. Also, genotype Assiut 201 was the best genotype under the experiment condition for the most studied characters. The interaction between $60 \mathrm{~N}$ unit of Enciabien and cultivar $17 / 8$ gave the highest averages of vine weight, main stem length and highest number of branches/plant, while the interaction between $40 \mathrm{~N}$ units of Enciabien and Assiut 201 gave the best number of marketable storage roots/plant, weight of marketable storage roots/plant, total yield/fed and average of root diameter. High dry matter content and high starch root percentage were obtained from genotype Assiut 201 when received any of four tested nitrogen levels. While, high percentage of fiber in sweet potato roots were obtained from the interaction between Assiut 202 and all levels of nitrogen. The highest percentage of sugar content in sweet potato roots was obtained from cultivar $17 / 8$ when received any of four used $\mathrm{N}$ levels.
\end{abstract}

\section{INTRODUCTION}

Sweet potato (Ipomoea batatas L. lam) is one of the most important popular vegetable crops in Egypt. It plays many roles in divorse food systems across the world. It has been cultivated for both food and starch manufacture.

Nitrogen is the most essential element in plant nutrition. Previous workers had shown that nitrogen particularly in relatively high doses could enhance sweet potato tuber yield, tuber size and tuber weight (Lee Hsinchen et al 1996; Marti \& Mills, 2002; Aresenaulat et al 2001 and Belanger et al 2002). Also, nitrogen has been reported to be an important element by many investigators due to its great effects on plant growth, N.P.K uptake and yield and its components for potato. Michael Bourke (1985) found that nitrogen had a greater influence on growth and yield for sweet potato. Nitrogen fertilization up to a rate of $225 \mathrm{~kg}$ $\mathrm{N}$ ha ${ }^{-1}$ increased tuber yield, mean tuber weight, total plant dry weight, dry weight of all plant components, leaf area index, leaf area duration, number of leaves per plant, mean leaf area per leaf, crop growth rate; and, for some periods, leaf area ratio (LAR) and relative growth rate. Damayanthi Gunarathna (1987) found that Excess $\mathrm{N}$-fertilizer (100 kg-N/ha) application to the soil led to high vegetative biomass production of sweet potato varieties resulting in low values of harvesting index and yield. Highest root yields were obtained at the $\mathrm{N}$-fertilizer level of $50 \mathrm{~kg}-\mathrm{N} / \mathrm{ha}$ with uncontrolled vine growth, i.e. 23.07 and $24.93 \mathrm{t} / \mathrm{ha}$ for both varieties, respectively. Under controlled vine growth, the highest $\mathrm{N}$-fertilizer level $(100 \mathrm{~kg}-\mathrm{N} / \mathrm{ha})$ led to higher yields in both varieties. El-Banna et al (2001) found that plant height, foliage fresh weight and foliage and tuber dry weight (\%) of potato plants cv."Diamant" was increased with increasing $\mathrm{N}$ rate up to $180 \mathrm{~kg}$ N $/ \mathrm{fed}$. Oliveria $(\mathbf{2 0 0 0})$ indicated that vegetative growth and dry matter per plant were increased with increasing $N$ rate up to $200 \mathrm{~kg}$ $\mathrm{N} /$ ha in potato. Avery wide range of $\mathrm{N}$ fertilizer requirements has been reported for sweet potato (Hill, 1984). Alfred et al (2000) found that marketable and non-marketable sweet potato yield was negatively affected by $\mathrm{N}$ fertilizers. High $\mathrm{N}$ applications yielded $26 \mathrm{Mg} \mathrm{ha}^{-1}$ more vines than the con- 
trol treatment. Despite the negative effect of $\mathrm{N}$ on sweet potato yield, sweet potato had a higher $\mathrm{N}$ use efficiency. Marti and Mills (2002). Studied the effects of nitrogen $(\mathrm{N})$ and potassium $(\mathrm{K})$ nutrition on yield, dry weight partitioning, and $\mathrm{N}$ - and $\mathrm{K}$ use efficiency of three sweet potato [Ipomoea batatas L. (Lam.)]. Differences in yield among cultivars depended on the $\mathrm{N}$ and $\mathrm{K}$ rates. Significant cultivar $x$ nutrient interactions were found for dry weight expressed on a per plant basis, but interactions were not significant when expressed as \% of the total dry weight.Cultivars did not differ significantly in $\mathrm{N}$ use efficiency.Dry weight partitioning to the storage roots, and $\mathrm{N}$ - and K-use efficiency decreased with each increment in the $\mathrm{N}$ rate. With each increment in the $\mathrm{K}$ rate, dry weight partitioning to the storage roots and $\mathrm{N}$ use efficiency increased, while K-use efficiency decreased. Yield, dry weight partitioning, or nutrient-use efficiency can be increased by manipulating nitrogen and potassium nutrition. The variability among cultivars in K-use efficiency and dry matter partitioning suggest that the development of cultivars with improved nutrient utilization is possible. Lyasse et al (2003) found that in sweet potato total and marketable yields of early maturing cultivars were significantly higher than of late maturing cultivars $(P<0.05)$. The single application of $\mathrm{N}$ resulted in significantly higher yield in storage roots than split application $(P<0.05)$. Physiological efficiency values were highly correlated with total marketable yields. Ademar P de Oliveira et al (2006) found that the most economical $\mathrm{N}$ level applied in the soil related to commercial roots yield was $144 \mathrm{~kg} \mathrm{ha}^{-1}$, with roots estimated yield of $19123 \mathrm{~kg} \mathrm{ha}^{-1}$. The nitrogen supplied in the soil was more efficient for the sweet potato to express its maximum commercial roots yield, with increment of $6555 \mathrm{~kg} \mathrm{ha}^{-1}$, when compared to the leaves application.

Slow-release nitrogen fertilizers are used to increase nitrogen use efficiency (NUE) and extend $\mathrm{N}$ availability over a growing plant season. Benefits from using these $\mathrm{N}$ fertilizers include increasing NUE by plants, reducing $\mathrm{N}$ losses, prolonging $\mathrm{N}$ availability and reducing potential risk of $\mathrm{N}$ pollution to water resources. Rizk (2001) indicated that Enciabein is more suitable fertilizer than organic fertilizer in early stage of potato growth. Also, many of investigators studied the behavior of plant yield to slow release fertilizers such as (Derar and Gendy, 1994; Mdhu et al 1997 and Wadas, 1998).

The objective of this work was study the effect of different levels of slow- release fertilizer for benefit of $\mathrm{N}$ elements on growth, yield and chemical properties and detected the amounts of $\mathrm{N}$ for the new lines of sweet potato in the reclaimed soil.
Two field experiments were performed during the two successive seasons of 2006 and 2007 at Arab El-Awammer Research Station (A.R.C.); Assiut, Egypt, to study the effect Enciabien as a slow- release fertilizer on vegetative characters and yield and its components of two sweet potato clones i.e., Assiut 201, 202 and one cultivar 17/8 in newly reclaimed soil. The experimental design was split-plot with three replicates. Levels of the slowrelease fertilizer were contributed as the main plots while sweet potato genotypes were randomly distributed in the sub-plot. Each experimental plots was $10.5 \mathrm{~m}^{2}$.It contained three rows with $3.5 \mathrm{~m}$ long and $1 \mathrm{~m}$ wide. One-dipper row was used for measuring the vegetative growth characters, while the other two rows were used for measuring the yield and its components. The planting date was 25 April in both seasons. All experimental plots received equal recommended amounts of potassium sulphate $\left(\mathrm{k}_{2} \mathrm{O}\right)$ and calcium superphosphate $\left(\mathrm{P}_{2} \mathrm{O}_{5}\right)$. All amounts of $\mathrm{P}_{2} \mathrm{O}_{5}$ were added during soil preparation while $\mathrm{K}_{2} \mathrm{O}$ were added two portion the first beginning 30 days after transplanting and the second after the first one with 30 days. Enciabien was added only once through soil preparation while the ammonium sulphate added after 30 days from planted. The experiment included four treatments as follow:-

1- $20 \mathrm{~N}$ units of nitrogen/fed as ammonium sulphate (control)

2- $20 \mathrm{~N}$ units of Enciabien/feddan

3- $40 \mathrm{~N}$ units of Enciabien/feddan

4-60 N units of Enciabien/feddan

During the two experimental seasons the following data were recorded on 10 plants for each treatment.

1- Vegetative characters i.e., Number of branches/plant, the main stem length $(\mathrm{cm})$ and weight of vines/plant $(\mathrm{kg})$ were measured.

2- Yield and its components i.e., Number of marketable storage roots/plant (suitable size and good shape), weight of marketable storage roots/plant $(\mathrm{Kg})$, total yield (ton/fed.), root length $(\mathrm{cm})$ and root diameter $(\mathrm{cm})$.

3- Chemical characters i.e., Dry matter percentage, root crude fibers content $(\mathrm{g} / \mathrm{100 \textrm {g }})$ measured according to Association of Official Analytical Chemists Official Methods of Analysis (A.O.A.C., 1965), starch root percentage based on fresh weight, was determined according to Poschenok (1976) and percent of total sugar in roots in fresh weight, was determined according to Ranganna (1977).

MATERIALS AND METHODS 


\section{Statistical analysis}

All obtained data were subjected to statistical analysis and mean's separation was made with Duncan;s Multiple Range Test at $5 \%$ level of as mentioned by Gommez and Gommez (1984).

\section{RESULTS AND DISCUSSION}

\section{A- Vegetative growth characters}

\section{1- Average of vine weight $(\mathrm{kg})$}

Data on the effect of slow- release fertilizer on three sweet potato genotypes are presented in Tables (1) and (2) for 2006 and 2007 seasons, respectively. The results indicated that weight of vine/ plant increased with increasing $\mathrm{N}$ units of Enciabien fertilizer. There are significant differences among the four levels of $\mathrm{N}$ in this character. Using $60 \mathrm{~N}$ units of Enciabien gave the highest value while, the check treatment gave the lowest values in both seasons, but there are no significant differences between both levels 40 and $60 \mathrm{~N}$ units in the second season. The cultivar $17 / 8$ was more responsive than other sweet potato genotypes to $\mathrm{N}$ fertilizer and gave the highest value for this trait in both seasons. The interaction effect between the sweet potato genotypes and $\mathrm{N}$ fertilizer are presented in Tables 1 and 2 . The results showed that the interaction between cultivar $17 / 8$ and $60 \mathrm{~N}$ unit of Enciabien was significantly higher than the other interactions except interaction 17/8 when received $40 \mathrm{~N}$ units of Enciabien in first season while in the second season the interaction 17/8 when received $40 \mathrm{~N}$ units of Enciabien gave the highest value in this trait.

\section{2- Main stem length (cm).}

The tallest main stems were obtained by applying $60 \mathrm{~N}$ units of Enciabien as compared with the other levels in both seasons (Tables 1 and 2). Also, plant in Assiut 202 genotype were the tallest plant in both seasons. The interaction between cultivar $17 / 8$ and $60 \mathrm{~N}$ unit of Enciabien gave the highest value as compared with the other interactions except the interaction between Assiut 202 and $60 \mathrm{~N}$ unit of Enciabien in first season in this trait.

\section{3- Number of branches / plant}

Data of number of branches/plant in Tables (1) and (2) indicated that both levels of $40 \mathrm{~N}$ and $60 \mathrm{~N}$ units of Enciabien gave significantly higher values than the other two used levels in both seasons. $17 / 8$ cultivar gave the highest number of branches/plant than the other genotypes, while Assiut 202 genotype showed the lowest values. The highest values in both seasons were obtained from the interactions between cultivar 17/8 when received $60 \mathrm{~N}$ unit of Enciabien.

The results on the vegetative growth characters indicated that there were increases in growth of sweet potato plants by using Enciabien because it contains nitrogen in mineral form so sweet potato plant absorbed it first so is necessary in the early stages. Also, the increase in vegetative growth characters were due to the increase in $\mathrm{N}$ levels of Enciabien so the highest levels of Enciabien gave the highest values of these characters. These results agree with those reported by Michael Bourke (1985); El-Banna et al (2001); Damayanthi Gunarathna (1987); Oliveria (2000) and Rizk (2001).

\section{B-Yield and its components}

\section{4- Number of marketable storage roots/plant}

The highest values of number of roots/plant were obtained when plants received 40 and $60 \mathrm{~N}$ units of Enciabien and there were no significant differences between these two levels in this character. Assiut 201 genotype gave significantly higher number of marketable storage roots/plant than the other tested genotypes. The interaction between Assiut 201 and fertilizering with $40 \mathrm{~N}$ units with Enciabien showed the highest values and was significantly higher than the other interactions for number of roots/plant in both seasons.

\section{5- Weight of marketable storage roots/plant}

Data in Tables (1) and (2) indicated that the 40 $\mathrm{N}$ units of Enciabien were significantly higher than the other levels of $\mathrm{N}$ in both seasons regarding this trait. Also, Assiut 201 genotype gave the highest weight of marketable storage roots/plant than the other two genotypes in both seasons. The interactions between sweet potato genotype and $\mathrm{N}$ fertilizer level indicated that Assiut 201 gave the highest value when received $40 \mathrm{~N}$ units of Enciabien in both seasons.

\section{6- Total yield (ton/fed)}

The estimated data (Tables 1 and 2 ) of total yield showed similar trend to that found for weight of marketable storage roots/plant .

\section{7- Average root length (cm)}

Data of average root length for the three sweet potato genotypes fertilized with four levels of $\mathrm{N}$ are presented in Tables 3 and 4. 
Table 1. Effeet of slow-release fertilizer on growth, yield and its components for three sweet potato genotypes in 2006.

\begin{tabular}{|c|c|c|c|c|c|c|c|c|c|}
\hline \multicolumn{4}{|c|}{ Characters } & $\begin{array}{l}\text { Average } \\
\text { of vine } \\
\text { weight } \\
\text { (kg) }\end{array}$ & $\begin{array}{l}\text { Main } \\
\text { stem } \\
\text { length } \\
(\mathrm{cm})\end{array}$ & $\begin{array}{l}\text { Number } \\
\text { of } \\
\text { branch- } \\
\text { es/ plant }\end{array}$ & $\begin{array}{c}\text { Number of } \\
\text { marketa- } \\
\text { ble stor- } \\
\text { age roots/ } \\
\text { plant }\end{array}$ & $\begin{array}{l}\text { Weight of } \\
\text { marketable } \\
\text { storage } \\
\text { roots/ plant } \\
(\mathrm{kg})\end{array}$ & $\begin{array}{c}\text { Total } \\
\text { yield } \\
\text { (ton/fed) }\end{array}$ \\
\hline \multicolumn{10}{|c|}{20 units $\mathrm{N}$ of ammonium } \\
\hline \multirow{5}{*}{\multicolumn{2}{|c|}{ 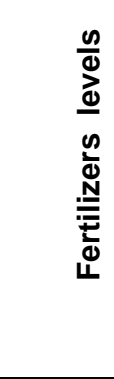 }} & \multirow{2}{*}{\multicolumn{2}{|c|}{$\begin{array}{l}\text { sulphate (Level A) } \\
20 \text { units } \mathrm{N} \text { of Enciabien }\end{array}$}} & $6.35 d$ & $148.1 \mathrm{~d}$ & $6.59 \mathrm{c}$ & $5.44 \mathrm{~b}$ & $1.97 \mathrm{~b}$ & $13.1 \mathrm{~b}$ \\
\hline & & & & & & & & & \\
\hline & & \multirow{2}{*}{\multicolumn{2}{|c|}{$\begin{array}{l}\text { (Level B) } \\
40 \text { units } \mathrm{N} \text { of Eciabien } \\
\text { (Level } \mathrm{C})\end{array}$}} & $6.76 \mathrm{c}$ & $164.7 \mathrm{c}$ & $7.57 \mathrm{~b}$ & $4.94 \mathrm{~b}$ & $1.55 \mathrm{c}$ & $11.4 \mathrm{c}$ \\
\hline & & & & $7.42 \mathrm{~b}$ & $173.1 \mathrm{~b}$ & $8.49 a$ & $6.79 \mathrm{a}$ & $2.53 \mathrm{a}$ & $14.3 \mathrm{a}$ \\
\hline & & \multicolumn{2}{|c|}{$\begin{array}{l}60 \text { Units } \mathrm{N} \text { ofEnciabien } \\
\text { (Level D) }\end{array}$} & $7.75 a$ & $187.4 \mathrm{a}$ & $8.83 a$ & $5.35 a$ & $1.60 \mathrm{c}$ & $11.2 \mathrm{c}$ \\
\hline \multirow{3}{*}{ 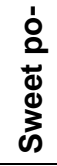 } & \multirow{3}{*}{ 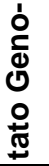 } & Assil & 1 (Genotype1) & $6.59 \mathrm{~b}$ & $148.4 \mathrm{c}$ & $7.97 \mathrm{~b}$ & $7.56 \mathrm{a}$ & $2.73 \mathrm{a}$ & $17.77 \mathrm{a}$ \\
\hline & & \multicolumn{2}{|c|}{ Assiut 202 (Genotype 2) } & $5.33 c$ & $183.4 \mathrm{a}$ & $6.81 \mathrm{c}$ & $5.16 b$ & $1.41 \mathrm{c}$ & $9.20 \mathrm{c}$ \\
\hline & & $17 / 8$ & (Genotype 3) & $9.29 a$ & $173.2 \mathrm{~b}$ & $8.83 \mathrm{a}$ & $4.16 \mathrm{c}$ & $1.60 \mathrm{~b}$ & $10.5 \mathrm{~b}$ \\
\hline \multirow{12}{*}{ 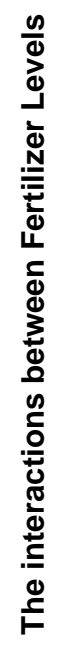 } & \multirow{12}{*}{ 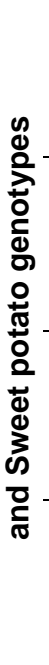 } & \multirow{3}{*}{$\frac{\varangle}{\Phi}$} & Genotype 1 & $5.56 \mathrm{fg}$ & $134.4 \mathrm{f}$ & $6.55 \mathrm{fg}$ & $7.75 \mathrm{~b}$ & $2.82 \mathrm{~b}$ & $17.9 \mathrm{~b}$ \\
\hline & & & Genotype 2 & $4.71 \mathrm{~h}$ & $173.7 \mathrm{~d}$ & $5.49 \mathrm{~g}$ & $4.78 \mathrm{de}$ & $1.38 \mathrm{f}$ & 9.8 ef \\
\hline & & & Genotype 3 & $8.78 \mathrm{c}$ & $136.2 \mathrm{f}$ & 7.73 cde & $3.78 \mathrm{f}$ & $1.71 \mathrm{e}$ & $11.5 \mathrm{~d}$ \\
\hline & & $\boldsymbol{m}$ & Genotype 1 & $6.11 \mathrm{e}$ & $137.4 \mathrm{f}$ & 7.57 def & $6.54 \mathrm{c}$ & $2.22 \mathrm{c}$ & $16.4 \mathrm{c}$ \\
\hline & & $\overbrace{\bar{\Phi}}^{\bar{\Phi}}$ & Genotype 2 & $5.07 \mathrm{gh}$ & $183.6 \mathrm{bc}$ & 6.73 ef & $4.34 \mathrm{def}$ & $1.18 \mathrm{f}$ & $8.4 \mathrm{~g}$ \\
\hline & & 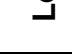 & Genotype 3 & $9.10 \mathrm{bc}$ & $173.2 \mathrm{~d}$ & $8.40 \mathrm{bcd}$ & 3.44 ef & $1.26 \mathrm{f}$ & $9.3 \mathrm{f}$ \\
\hline & & $\underline{0}$ & Genotype 1 & $7.24 \mathrm{~d}$ & $146.7 \mathrm{e}$ & $8.80 \mathrm{abc}$ & $9.01 \mathrm{a}$ & $3.61 \mathrm{a}$ & $20.3 a$ \\
\hline & & $\sum_{0}^{\bar{\Phi}}$ & Genotype 2 & 5.61 ef & $185.9 b$ & 7.26 ef & $6.27 c$ & $1.89 \mathrm{de}$ & $10.4 \mathrm{e}$ \\
\hline & & & Genotype 3 & $9.40 \mathrm{sb}$ & $186.8 \mathrm{~b}$ & $9.39 a b$ & $5.10 \mathrm{~d}$ & $2.10 \mathrm{~cd}$ & $12.3 d$ \\
\hline & & $\underline{-}$ & Genotype 1 & $7.44 \mathrm{~d}$ & $175.1 \mathrm{~cd}$ & $8.95 a b$ & $6.94 \mathrm{bc}$ & $2.25 \mathrm{c}$ & $16.46 \mathrm{c}$ \\
\hline & & $\overbrace{0}^{\bar{\Phi}}$ & Genotype 2 & 5.94 ef & $190.4 a b$ & 7.73 cde & $5.27 \mathrm{~d}$ & $1.21 \mathrm{f}$ & $8.22 \mathrm{~g}$ \\
\hline & & & Genotype 3 & $9.87 \mathrm{a}$ & $196.7 \mathrm{a}$ & $9.80 \mathrm{a}$ & 3.84 ef & $1.34 \mathrm{f}$ & $8.93 \mathrm{fg}$ \\
\hline
\end{tabular}

* Means within the same colum for each of fertilizer levels, sweet potato genotypes, or their interactions followed by the same letter (s) at $p=0.05$ are not statistically differed 
Table 2. Effect of slow-release fertilizer on growth, yield and its components for three sweet potato genotypes in 2007.

\begin{tabular}{|c|c|c|c|c|c|c|c|c|}
\hline & \multicolumn{2}{|c|}{ Characters } & $\begin{array}{l}\text { Average } \\
\text { of vine } \\
\text { weigh } \\
(\mathrm{kg})\end{array}$ & $\begin{array}{l}\text { Main } \\
\text { stem } \\
\text { length } \\
(\mathrm{cm})\end{array}$ & $\begin{array}{c}\text { Num- } \\
\text { ber of } \\
\text { branch } \\
\text { es/ } \\
\text { plant }\end{array}$ & $\begin{array}{c}\text { Number of } \\
\text { marketable } \\
\text { storage } \\
\text { roots/ } \\
\text { plant }\end{array}$ & $\begin{array}{l}\text { Weight of } \\
\text { marketable } \\
\text { storage } \\
\text { roots/ plant } \\
(\mathrm{kg})\end{array}$ & $\begin{array}{l}\text { Total yield } \\
\text { (ton/fed.) }\end{array}$ \\
\hline \multirow{4}{*}{ 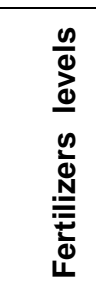 } & \multirow{4}{*}{\multicolumn{2}{|c|}{$\begin{array}{l}20 \text { units } N \text { of ammoni- } \\
\text { um sulphate (Level A) } \\
20 \text { units } N \text { of Enciabien } \\
\text { (Level B) } \\
40 \text { units } N \text { of Enciabien } \\
\text { (Level C) } \\
60 \text { Units N of Enciabien } \\
\text { (Level D) }\end{array}$}} & $6.0 \mathrm{c}$ & $140.0 \mathrm{~d}$ & $6.8 \mathrm{~d}$ & $5.3 \mathrm{~b}$ & $1.6 \mathrm{~b}$ & $11.8 \mathrm{~b}$ \\
\hline & & & $7.0 \mathrm{~b}$ & $170.1 \mathrm{~b}$ & $7.4 \mathrm{c}$ & $5.6 \mathrm{~b}$ & $2.4 \mathrm{a}$ & $11.3 \mathrm{bc}$ \\
\hline & & & $7.8 \mathrm{a}$ & $182.1 \mathrm{~b}$ & $8.3 b$ & $7.7 \mathrm{a}$ & $1.5 b$ & $15.0 \mathrm{a}$ \\
\hline & & & $8.0 \mathrm{a}$ & $190.7 \mathrm{a}$ & $8.8 \mathrm{a}$ & $5.4 b$ & $2.4 \mathrm{a}$ & $11.3 \mathrm{c}$ \\
\hline \multirow{3}{*}{ 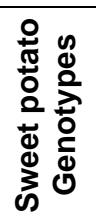 } & \multirow{2}{*}{\multicolumn{2}{|c|}{$\begin{array}{l}\text { Assiut } 201 \\
\text { (Genotype 1) } \\
\text { Assiut } 202 \\
\text { (Genotype 2) }\end{array}$}} & $7.2 \mathrm{~b}$ & $158.8 \mathrm{c}$ & $8.0 \mathrm{a}$ & $7.7 \mathrm{a}$ & $1.4 \mathrm{c}$ & $17.5 \mathrm{a}$ \\
\hline & & & $6.0 \mathrm{c}$ & $183.7 \mathrm{a}$ & $7.1 \mathrm{~b}$ & $5.5 b$ & $1.5 b$ & $9.2 \mathrm{c}$ \\
\hline & $17 / 8$ & (Genotype 3) & $8.4 \mathrm{a}$ & $176.4 \mathrm{~b}$ & $8.4 \mathrm{a}$ & $4.8 \mathrm{c}$ & $2.1 \mathrm{bc}$ & $10.4 \mathrm{~b}$ \\
\hline \multirow{12}{*}{ 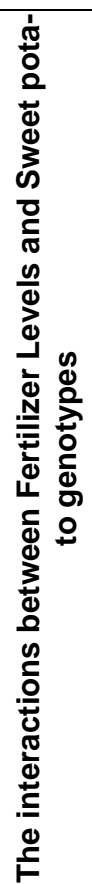 } & \multirow{3}{*}{$\frac{\nwarrow}{\Phi}$} & Genotype 1 & $5.7 \mathrm{fg}$ & $135.1 \mathrm{i}$ & $7.3 \mathrm{de}$ & $6.7 \mathrm{~b}$ & $1.3 \mathrm{e}$ & $16.7 \mathrm{~b}$ \\
\hline & & Genotype 2 & $4.6 \mathrm{~g}$ & $170.6 \mathrm{f}$ & $5.8 f$ & $4.8 \mathrm{~cd}$ & $1.3 \mathrm{e}$ & $8.6 \mathrm{gh}$ \\
\hline & & Genotype 3 & $7.6 \mathrm{cde}$ & $141.4 \mathrm{~h}$ & $7.4 \mathrm{~d}$ & $4.5 \mathrm{~cd}$ & $2.3 \mathrm{~b}$ & $10.2 \mathrm{e}$ \\
\hline & \multirow{3}{*}{$\frac{\boldsymbol{m}}{\grave{d}}$} & Genotype 1 & $7.0 \mathrm{de}$ & $149.1 \mathrm{~g}$ & $7.5 \mathrm{~cd}$ & $7.4 \mathrm{~b}$ & $1.2 \mathrm{e}$ & $16.0 \mathrm{~b}$ \\
\hline & & Genotype 2 & $5.9 f$ & $183.8 \mathrm{~cd}$ & 6.5 ef & $5.1 \mathrm{c}$ & $1.4 \mathrm{e}$ & $8.7 \mathrm{fgh}$ \\
\hline & & Genotype 3 & $8.1 \mathrm{abcd}$ & $177.3 \mathrm{e}$ & $8.1 \mathrm{bcd}$ & $4.2 \mathrm{~cd}$ & $3.3 \mathrm{a}$ & $9.3 \mathrm{fg}$ \\
\hline & \multirow{3}{*}{$\frac{0}{0}$} & Genotype 1 & $7.8 \mathrm{bcd}$ & $169.7 \mathrm{f}$ & $8.4 \mathrm{bc}$ & $9.3 \mathrm{a}$ & $1.9 \mathrm{~d}$ & $21.3 \mathrm{a}$ \\
\hline & & Genotype 2 & 6.5 ef & 188.6 bc & $7.8 \mathrm{~cd}$ & $7.3 \mathrm{~b}$ & $2.0 \mathrm{c}$ & $11.2 \mathrm{~d}$ \\
\hline & & Genotype 3 & $9.1 \mathrm{a}$ & $187.9 \mathrm{bc}$ & $8.8 a b$ & $6.6 \mathrm{~b}$ & $2.1 \mathrm{c}$ & $12.5 \mathrm{c}$ \\
\hline & \multirow{3}{*}{$\frac{0}{\Phi}$} & Genotype 1 & $8.1 \mathrm{abc}$ & $181.2 \mathrm{de}$ & $8.8 \mathrm{ab}$ & $7.2 \mathrm{~b}$ & $1.2 \mathrm{e}$ & $16.0 \mathrm{~b}$ \\
\hline & & Genotype 2 & $7.0 \mathrm{de}$ & $191.7 \mathrm{~b}$ & $8.3 \mathrm{bc}$ & $4.8 \mathrm{~cd}$ & $1.4 \mathrm{e}$ & $8.4 \mathrm{~h}$ \\
\hline & & Genotype 3 & $8.7 \mathrm{ab}$ & $199.2 \mathrm{a}$ & $9.3 \mathrm{a}$ & $4.1 \mathrm{~d}$ & $1.6 \mathrm{~b}$ & 9.5 ef \\
\hline
\end{tabular}

* Means within the same column for each of fertilizer levels, sweet potato genotypes, or their interactions followed by the same letter (s) at $\mathrm{p}=0.05$ are not statistically differed 
Table 3. Effect of slow-release fertilizer on root length, root diameter and chemical characters for three sweet potato genotypes in 2006.

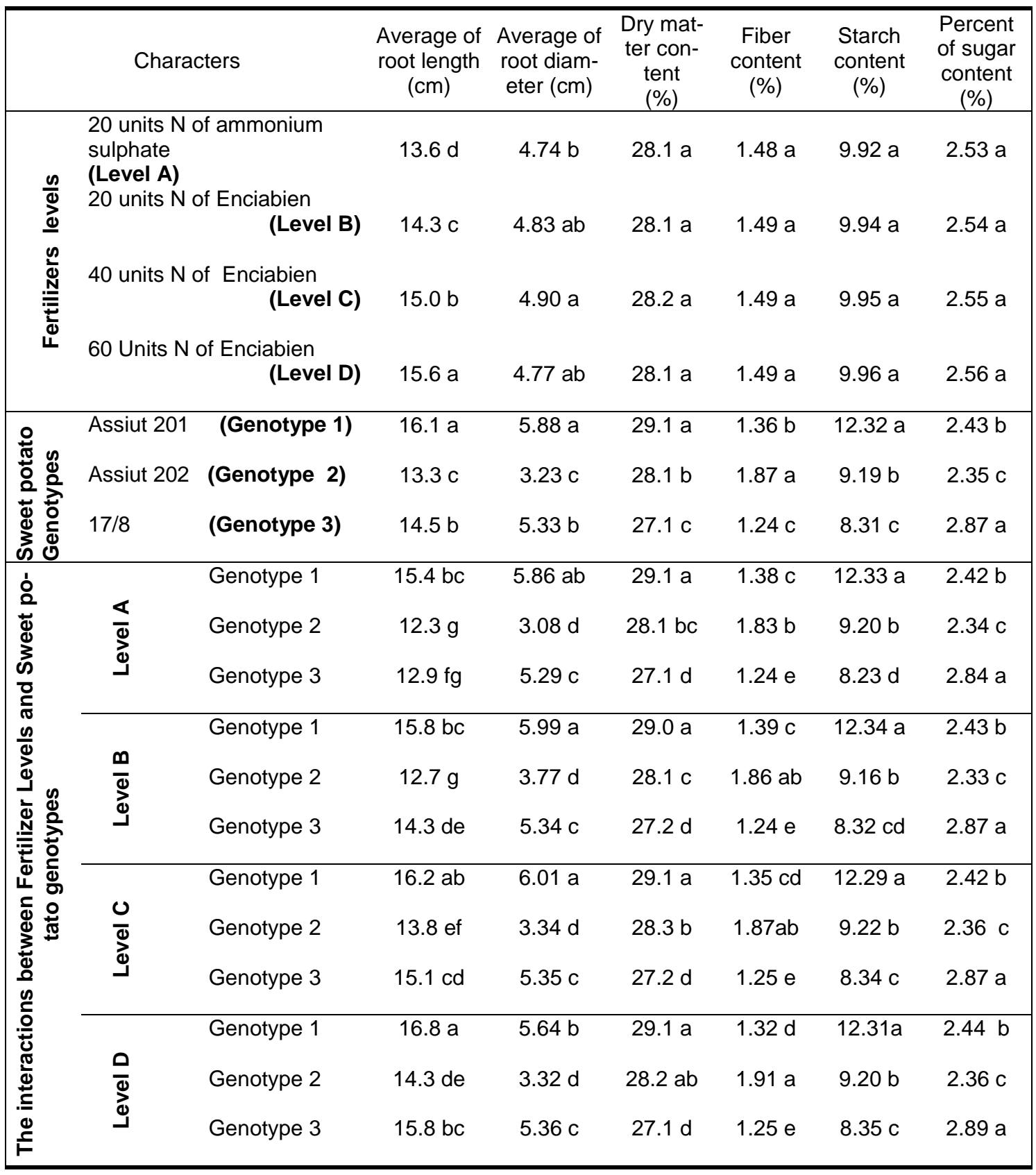

* Means within the same column for each of fertilizer levels, sweet potato genotypes, or their interactions followed by the same letter (s) at $\mathrm{p}=0.05$ are not statistically differed 
Table 4. Effect of slow-release fertilizer on root length, root diameter and chemical characters for three sweet potato genotypes in 2007.

\begin{tabular}{|c|c|c|c|c|c|c|c|c|}
\hline \multicolumn{3}{|c|}{ Characters } & $\begin{array}{l}\text { Average } \\
\text { of root } \\
\text { length } \\
(\mathrm{cm})\end{array}$ & $\begin{array}{l}\text { Average } \\
\text { of root } \\
\text { diameter } \\
(\mathrm{cm})\end{array}$ & $\begin{array}{l}\text { Dry mat- } \\
\text { ter con- } \\
\text { tent } \\
(\%)\end{array}$ & $\begin{array}{c}\text { Fiber } \\
\text { content } \\
(\%)\end{array}$ & $\begin{array}{c}\text { Starch } \\
\text { content } \\
(\%)\end{array}$ & $\begin{array}{c}\text { Percent } \\
\text { of suger } \\
\text { content } \\
(\%)\end{array}$ \\
\hline \multirow{5}{*}{ 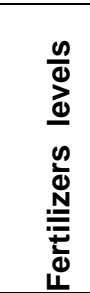 } & \multicolumn{2}{|c|}{20 units $\mathrm{N}$ of ammonium } & $14.0 \mathrm{c}$ & $4.9 \mathrm{~b}$ & $28.2 \mathrm{a}$ & $1.5 \mathrm{a}$ & $10.0 \mathrm{a}$ & $2.5 \mathrm{a}$ \\
\hline & \multirow{2}{*}{\multicolumn{2}{|c|}{$\begin{array}{l}\text { sulphate } \quad((\text { Level } A) \\
20 \text { units } N \text { of Enciabien } \\
\text { (Level B) }\end{array}$}} & & & & & & \\
\hline & & & $14.5 \mathrm{bc}$ & $5.3 \mathrm{~b}$ & $28.2 \mathrm{a}$ & $1.5 \mathrm{a}$ & $10.0 \mathrm{a}$ & $2.5 \mathrm{a}$ \\
\hline & \multicolumn{2}{|c|}{$\begin{array}{l}40 \text { units } \mathrm{N} \text { of Enciabien } \\
\text { (Level C) }\end{array}$} & $14.9 a b$ & $5.8 \mathrm{a}$ & $28.2 \mathrm{a}$ & $1.5 \mathrm{a}$ & $10.0 \mathrm{a}$ & $2.5 \mathrm{a}$ \\
\hline & \multicolumn{2}{|c|}{$\begin{array}{l}60 \text { Units } N \text { of Enciabien } \\
\text { (Level D) }\end{array}$} & $15.5 \mathrm{a}$ & $5.2 \mathrm{~b}$ & $28.3 \mathrm{a}$ & $1.5 \mathrm{a}$ & $10.0 \mathrm{a}$ & $2.5 \mathrm{a}$ \\
\hline \multirow{3}{*}{ 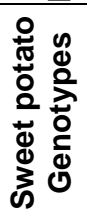 } & \multicolumn{2}{|c|}{ Assiut $201 \quad$ (Genotype 1) } & $16.3 \mathrm{a}$ & $6.2 \mathrm{a}$ & $29.1 \mathrm{a}$ & $1.4 \mathrm{~b}$ & $12.4 \mathrm{a}$ & $2.4 \mathrm{~b}$ \\
\hline & \multicolumn{2}{|c|}{ Assiut 202 (Genotype 2) } & $14.0 \mathrm{~b}$ & $3.5 b$ & $28.4 \mathrm{~b}$ & $1.9 \mathrm{a}$ & $9.2 \mathrm{~b}$ & $2.3 \mathrm{c}$ \\
\hline & $17 / 8$ & Genotype 3) & $13.9 \mathrm{~b}$ & $6.2 \mathrm{a}$ & $27.2 \mathrm{c}$ & $1.3 \mathrm{c}$ & $8.4 \mathrm{c}$ & $2.9 \mathrm{a}$ \\
\hline \multirow{12}{*}{ 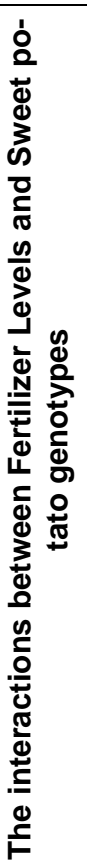 } & \multirow{3}{*}{$\frac{\varangle}{\Phi}$} & Genotype 1 & $16.0 \mathrm{abc}$ & $5.8 \mathrm{c}$ & $29.1 \mathrm{a}$ & $1.3 \mathrm{~b}$ & $12.3 \mathrm{a}$ & $2.4 \mathrm{~b}$ \\
\hline & & Genotype 2 & $13.3 \mathrm{fg}$ & $3.3 \mathrm{de}$ & $28.3 \mathrm{~b}$ & $1.9 \mathrm{a}$ & $9.3 \mathrm{~b}$ & $2.3 \mathrm{c}$ \\
\hline & & Genotype 3 & $12.8 \mathrm{~g}$ & $5.7 \mathrm{c}$ & $27.2 \mathrm{c}$ & $1.2 \mathrm{c}$ & $8.3 \mathrm{c}$ & $2.9 \mathrm{a}$ \\
\hline & \multirow{3}{*}{$\frac{m}{\Phi}$} & Genotype 1 & $16.4 \mathrm{ab}$ & $5.9 \mathrm{bc}$ & $29.0 \mathrm{a}$ & $1.4 \mathrm{~b}$ & $12.4 \mathrm{a}$ & $2.4 \mathrm{~b}$ \\
\hline & & Genotype 2 & 14.2 ef & $3.7 \mathrm{de}$ & $28.4 \mathrm{~b}$ & $1.9 \mathrm{a}$ & $9.2 \mathrm{~b}$ & $2.3 \mathrm{c}$ \\
\hline & & Genotype 3 & $13.1 \mathrm{~g}$ & $6.1 \mathrm{abc}$ & $27.2 \mathrm{c}$ & $1.2 \mathrm{c}$ & $8.4 \mathrm{c}$ & $2.9 \mathrm{a}$ \\
\hline & \multirow{3}{*}{$\frac{0}{\Phi}$} & Genotype 1 & $15.9 \mathrm{bc}$ & $6.8 \mathrm{a}$ & $29.2 \mathrm{a}$ & $1.4 \mathrm{~b}$ & $12.4 \mathrm{a}$ & $2.4 \mathrm{~b}$ \\
\hline & & Genotype 2 & 14.4 def & $3.9 \mathrm{~d}$ & $28.3 b$ & $1.9 \mathrm{a}$ & $9.2 \mathrm{~b}$ & $2.3 \mathrm{c}$ \\
\hline & & Genotype 3 & $14.5 \mathrm{de}$ & $6.6 a b$ & $27.2 \mathrm{c}$ & $1.3 \mathrm{c}$ & $8.4 \mathrm{c}$ & $2.9 \mathrm{c}$ \\
\hline & \multirow{3}{*}{$\frac{0}{\Phi}$} & Genotype 1 & $17.0 \mathrm{a}$ & $6.3 \mathrm{abc}$ & $29.1 \mathrm{a}$ & $1.4 \mathrm{~b}$ & $12.4 \mathrm{a}$ & $2.4 \mathrm{~b}$ \\
\hline & & Genotype 2 & 14.2 def & $3.1 \mathrm{e}$ & $28.5 \mathrm{~b}$ & $1.9 \mathrm{a}$ & $9.2 \mathrm{~b}$ & $2.3 \mathrm{c}$ \\
\hline & & Genotype 3 & $15.3 \mathrm{~cd}$ & $6.2 \mathrm{abc}$ & $27.2 \mathrm{c}$ & $1.3 \mathrm{c}$ & $8.4 \mathrm{c}$ & $2.9 \mathrm{a}$ \\
\hline
\end{tabular}

* Means within the same column for each of fertilizer levels, sweet potato genotypes, or their interactions followed by the same letter (s) at $\mathrm{p}=0.05$ are not statistically differed

$60 \mathrm{~N}$ units of Enciabien gave the highest value than the other levels in first season but in the second season there were no significant differences between 60 and $40 \mathrm{~N}$ units. Assiut 201 genotype gave the highest length of root in both seasons in this trait. The interaction between $\mathrm{N}$ levels and sweet potato genotype indicated that Assiut 201 gave the highest values when received $60 \mathrm{~N}$ units of Enciabien in both seasons.

\section{8- Average of root diameter (cm)}

In Tables (3 and 4) there were no significant differences among the three used levels of Enciabien for average of root diameter in the first season while in the second season $40 \mathrm{~N}$ units of Enciabien gave the highest value and indicated higher significant differences than the other levels. Genotype Assiut 201 gave the highest value in the first sea- 
son but in the second season there was no significant difference between it and 17/8 cultivar for average of root diameter. The interaction between Assiut 201 genotype when received $40 \mathrm{~N}$ unit of Enciabien gave the highest value for this characters in both seasons.

The increase in yield of sweet potato may be attributed to the number of leaves, shoots and weight of fresh and dry weight of the whole plant. Also, the addition of Enciabien to the soil as a slow- release fertilizer facilitated the availability of $\mathrm{N}$ in root zone which is related to be increase in sweet potato plant. Some investigators studied the behavior of plant yield to slow- release fertilizer and obtained results supported our finding (Derar \& Gendy, 1994; Mdhu et al 1997 and Wadas, 1998). Also, the increase in $\mathrm{N}$ levels of Enciabien resulted in an increase in total yield of sweet potato and these results were in agreement with those of Lee Hsinchen et al 1996; Marti \& Mills, 2002; Aresenaulat et al 2001; Belanger et al 2002; Lyasse et al 2003 and Ademar P de Oliveira et al 2006

\section{C- Chemical characters}

\section{9- Dry matter content}

There were no significant differences among all tested levels of $\mathrm{N}$ for this character in both seasons (Tables 3 and 4). Assiut 201 genotype gave significantly higher values than the other sweet potato genotypes in dry matter content in both seasons. The highest value for this trait was obtained from Assiut 201 genotype when received 40 $\mathrm{N}$ units of Enciabien fertilizer in both seasons.

\section{0- Percentage of crud fibers}

The response of three sweet potato genotypes to four levels of $\mathrm{N}$ indicated that there were no significant differences among the four levels of $\mathrm{N}$ in percentage of fibers in the storage roots of sweet potato genotypes in both seasons. It is obvious from the data that Assiut 202 genotype gave the highest percentage of fibers than the other used sweet potato genotypes in both seasons. The interaction between sweet potato genotypes and $\mathrm{N}$ levels showed that Assiut 202 genotype when received the three levels of Enciabien was significantly higher than both interactions in both seasons.

\section{1- Percentage of Starch}

Data in Tables (3) and (4) indicated that there were no significant differences among the four $\mathrm{N}$ levels in this trait in both seasons. The highest values of starch were obtained from Assiut 201 genotype in both seasons and it was significantly higher than the other sweet potato genotypes. The interaction between sweet potato genotypes and $\mathrm{N}$ levels showed that the highest values for this trait were obtained from the interaction between Assiut 201 when received any of the four tested $\mathrm{N}$ levels and there were no significant differences among these four interactions.

\section{2- Percentage of sugar content}

There were no significant differences among the four $\mathrm{N}$ levels in both seasons for sugar content character. The highest values of sugar content were obtained from 17/8 cultivar in both seasons. The interactions between sweet potato genotypes and $\mathrm{N}$ levels showed that the highest values for this trait were obtained from the interactions between 17/8 cultivar when received any of the four used $\mathrm{N}$ levels and there were no significant differences among these four interactions while, these interactions were significantly higher than the other interactions in both seasons.

The results indicated that there were no significant differences in the chemical characters as affected by fertilizer levels, but there were significant differences among the three tested genotypes. So, the significant interactions between sweet potato genotypes and $\mathrm{N}$ fertilizer levels were dependent up on the sweet potato genotypes. Some workers found that there were significant differences among sweet potato cultivars in plant height, plant chemical composition and yield and its components (Shalaby et al 1993 and Hewedy et al 1999).

\section{REFERENCES}

Ademar P de Oliveira; M.F. de Moura; D.H. Nogueira; N.G. Chagas; M.S. Braz; M.R. T. de Oliveira and J. A. Barbosa (2006). Yield of sweet potato roots in function of nitrogen levels applied in soil and foliating. Hort. Bras., 24(3): 224-246. Brasília July/Sept. 2006

Alfred E. Hartemink; M. Johnston; J.N. O'Sullivan and S. Poloma (2000). Nitrogen use efficiency of taro and sweet potato in the humid lowlands of Papua New Guinea. Agriculture, Ecosystems and Environment, 79: 271-280.

Aresenaulat, W.D.; A.I. Dabby; C.C.T. George and P. Boswall (2001). Nitrogen application and seed pieces on yield and tuber size in eight potato cultivars. Amer. J. Potato Res. 78:301-309.

Association of Official Analytical Chemists (A.O.A.C.) (1965). Official and Tentative Methods of Analysis. 10th Ed., 1008 pp. Washington. D.C.

Belanger, G.; J.R. Walsh; J.E. Richards; P.H. Mibun and N. Ziadi (2002). Nitrogen fertilization and irrigation effects on tuber characteristics of two 
potato cultivars. Amer. J. Potato Res. 79(4): 269279.

Damayanthi Gunarathna, G.A.M. (1988). Effect of $\mathrm{N}$-fertilizer and method of control of vine growth on tuber yield of sweet potato (Ipomea batatas L. Lam.). In: Training Report 1988, pp. 141-148. Top/ AVRDC, Kasetsart University, Bangkok, Thailand.

Derar, R.A. and E.N. Gendy (1994). Effect of Nfertlizer and faramyared manure under $\mathrm{Fe}$ and $\mathrm{Mn}$ foliation and Broad bean plant. Egypt. J. Appl. Sci., 9(6):11-18.

El-Banna, E.N.; E.M. Awed; H.M. Ramadan and M.R. Mohammed (2001). Effect of Bio-Organic fertilization in different season on growth, yield and tubers quality of potato (Solanum tuberosum). J. Agric. Sci. Mansoura. Univ., 26(3): 1687-1696.

Gommez, K.A. and A.A. Gommez (1984). Statistical Procedure for Agric. Res. $2^{\text {nd }}$ Ed, 680 PP. John Wiley and Sons Inc. New York,.

Hewedy ,A.M.; H. Asfour and A. H. Amer (1999). Comparison studies on yield and its characters of some sweet potato cultivars and clones at two different new sandy reclaimed soil locations. J. Appl. Sci. 14(3): 215-230.

Hill, W.A. (1984). Effect of nitrogen nutrition on quality of three important root/tuber crops. In: Hauck, R.D. (ed.), Nitrogen in Crop Production. pp. 627-641. ASA-CSSA-SSSA, Madison.

Lee-Hsinchen; Lai-X. Ungchang; Chen Yisin; Lee-Hc; Lai Y. and Y. Chem (1996). Effect of plant spacing and nitrogen fertilizer application on the leaf tips yield of leafy sweet potato. J. Agric. Rec. of China 45(3m): 230-240.

Lyasse, O.; N. Sanginga; B. Vanlauwe; J. Diels and R. Merckx (2003). The influence of source and timing of nitrogen fertilizers on yield and nitrogen use efficiency of four sweet potato cultivars.
Agriculture, Ecosystems \& Amp; Environment, $100(2 / 3)$ 201-207.

Marti H.R. and H.A. Mills (2002). Nitrogen and potassium nutrition affect yield, dry weight partitioning, and nutrient-use efficiency of sweet potato. Communications in Soil Science and Plant Analysis, 33: 287-301.

Mdhu, M.; N. Seshachalam; S.K. Nalatwadmath and P.H. Nimje (1997). Effect of organic and inorganic fertilizers on yield of crops and physicochemical properties of soil in high hills of Nilgiris (India). Indian J. of Soil-Conservation, 25(3): 241-245.

Michael Bourke, R. (1985). Influence of nitrogen and potassium fertilizer on growth of sweet potato (Ipomoea batatas) in Papua New Guinea. Field Crops Research. 12: 363-375.

Oliveria, C.D.S. (2000). Potato crop growth as affected by nitrogen and plant density. Pesquisa. Agropecuaria. Brasileria. 35 (5): 939-950.

Poschenok, N. (1976). Biochemical Analytical Methods of Plants. pp. 127-143. Publishers, Naokara, Kieve (In Russian).

Ranganna, S. (1977). Manual of Analysis of Fruit and Vegvtable Prodcts. pp. 9-20. Tata Mc Graw Hill Publishing Company Limited. New Delhi. Rizk A.F. (2001). Effect of some slow release nitrogen fertilizers on growth and yield of potato plants. J. Agric. Sci. Mansoura Univ., 26 (9): 5671-5686.

Shalaby, G.I.; S.A. Abdella; A.M. Damarany and A.M. Abd Elsalam (1993). Evaluation of some cultivars and breeding genotypes of sweet potato under Assiut conditions. 1 . Vine and storage root yield data. Assiut J. Agric. Sci. 24(1):315-328.

Wadas, W. (1998). Productive effect of different forms of organic fertilizer applied in vegetable cultivation. Roczniki-Nauk-Rolniczch- Seria- AProduckcja- Roslinua, 113(1-2): 201-211. 